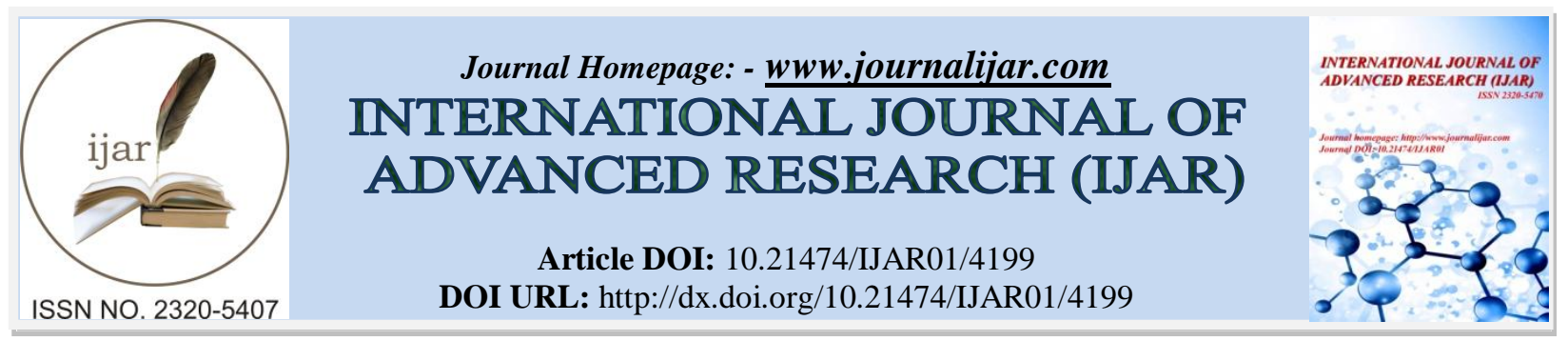

CASE REPORT

\title{
COMPLETE REMISSION OF ACUTE LYMPHOBLASTIC LEUKEMIA WITH CITRIC ACID AS A TREATMENT.
}

\author{
Alberto Halabe Bucay. \\ Fundacion "Dr Alberto Halabe" Prado Norte 460, Lomas de Chapultepec, 11000, Mexico.
}

\section{Manuscript Info}

Manuscript History

Received: 13 March 2017

Final Accepted: 11 April 2017

Published: May 2017

Key words:-

Cancer; treatment; citric acid; acute

lymphoblastic leukemia

\section{Abstract}

This article describes the case of a female patient diagnosed with acute lymphoblastic leukemia who was treated with only citric acid when she was 14 years old, considered as a high risk diagnosis, and its complete remission after 45 days of treatment with citric acid.

\section{Case report:-}

This is a 14 years old female patient who was diagnosed with precursor B acute lymphoblastic leukemia,on July 19, 2015, confirmed by a bone marrow biopsy performed at the Hospital Infantil de México "Federico Gómez", considered as high risk for age and leukopenia at the time of diagnosis, she began receiving chemotherapy and complete treatment for lymphoblastic leukemia, the last chemotherapy was on October 15, 2015. The treatment with citric acid that I indicated was started on October 20,2015, 5 to 7 grams each day, as is described in my article (1) which was her only treatment.

The general conditions of the patient begins to improve in all aspects, and 45 days after starting the treatment with citric acid, on December $4^{\text {th }}, 2015$, the patient's hematological biometry performed by flow citometry reported hemoglobin $15.1 \mathrm{~g} / \mathrm{dl}$, total leucocytes 6,200 per $\mathrm{mm} 3$, with $59.5 \%$ of neutrophils, $33.7 \%$ of lymphocytes, $5.4 \%$ of monocytes and $1 \%$ of eosinophils, without lymphoid blasts and 234,000 platelets.

The report of all normal haematological values, hemoglobin, leucocytes and platelets as well as the absence of peripheral lymphoid blasts determined by flow cytometry is confirmation of remission of leukemia, particularly precursor B acute lymphoblastic leukemia (2).

\section{Conclusion:-}

I have already reported 13 cases of patients with cancer who have improved impressively only with the citric acid treatment that they have received, considering that they are literally cured, including a patient with medullary thyroid cancer (3), patients with peritoneal mesothelioma (4) myeloid leukemia (5), Hürthle thyroid tumor (6), endocrine hepatic tumor (7), esophageal cancer (8), multiple myeloma (9), glioblastoma multiforme (10), pancreatic cancer (11) Non Hodgkin lymphoma (12) bladder cancer (13), breast cancer (14) and a patient with multiple myeloma remitted only in 10 days with the treatment of citric acid that she received (15); this case of remission of acute lymphoblastic leukemia only with the treatment of citric acid received will be the 14th reported worldwide..

Corresponding Author:- Alberto Halabe Bucay.

Address:- Fundacion "Dr Alberto Halabe" Prado Norte 460, Lomas de Chapultepec, 11000,

Mexico. 
All this undisputed evidence is enough to recognize that citric acid is effective as a cancer treatment, based on the Scientific Method of Claude Bernard.

\section{Discussion:-}

This work is completely ethical, citric acid is a food.

There are not conflicts of interest or financial disclosures.

\section{References:-}

1. Halabe Bucay A Proposal: Development of a Protocol based on clinical experience with patients with cancer who have improved after taking citric acid orally. Indian J Appl Res 2015;5(6):810

2. Dworzak MN, Fritsch G, Panzer-Grumayer ER, Mann G, Gadner H. Detection of residual disease in pediatric B-cell precursor acute lymphoblastic leukemia by comparative phenotype mapping: method and significance. Leuk Lymphoma 2000;38(3-4):295-308

3. Halabe Bucay A. Hypothesis proved... citric acid (citrate) does improve cancer: A case of a patient suffering from medullary thyroid cancer. Med Hypotheses 2009;73(2):271

4. Bucay AH. Clinical report: A patient with primary peritoneal mesothelioma that has improved after taking citric acid orally. Clin Res Hepatol Gastroenterol 2011:35:241

5. Halabe Bucay A. Report of a patient with leukemia who improved after taking citric acid orally. Glob Adv Res J Med and Medical Sci (GARJMMS) 2013;2: 280-281

6. Halabe Bucay A. Case Report: A patient with a thyroid tumor that was reduced more tan $50 \%$ after taking citric acid orally. Int J Curr Med Res 2014;3: 028-029

7. Halabe Bucay A. A patient with endocrine hepatic tumor who improved after taking citric acid orally. Int $\mathbf{J}$ Innovat Applied Res 2014;2:16-17

8. Halabe Bucay A. Pathological report of a patient with cancer of the esophagus improved considerably after receiving citric acid orally. Glob Adv Res J Med and Medical Sci (GARJMMS) 2014;3:159

9. Halabe Bucay A. Remission of multiple myeloma after receiving only citric acid orally. Glob Adv Res J Med and Medical Sci (GARJMMS) 2014;3:223-224

10. Halabe Bucay A. A patient with glioblastoma multiforme who improved after taking citric acid orally. Int Res J Basic Clin Stud 2015;3(1):35-37

11. Halabe Bucay A. Case Report: A Patient with pancreatic cancer who improved after the treatment with citric acid that she received. Indian J Appl Res 2015;5(12):392

12. Halabe Bucay A. A patient with Non Hodgkin Lymphoma that has survived more than 5 years after the treatment with citric acid that he received. Int J Res and Review 2015;2(12):769-770

13. Halabe Bucay A. Case Report: A patient with invasive bladder cancer who improved after the treatment of citric acid that he received. Int J Sci Res 2016;5(5):613

14. Halabe Bucay A. A patient with breast cancer that dissapeared after the treatment with citric acid that she received. Int J Sci Res 2016;5(6):533

15. Halabe Bucay A. Citric acid (citrate) is the cure of cancer: the case of a patient with complete remission of multiple myeloma in 10 days after the treatment with citric acid that she received. Int J SCi Res 2016;5(12):683. 